\title{
PESANTREN SALAF: PERUBAHAN SOSIAL DAN SUBLIMASI IDENTITAS DENGAN KOMBINASI TASAWUF, FIQIH DAN TAUHID (Model Pesantren di Kabupaten Tasikmalaya Jawa Barat)
}

\author{
Muhammad Solahudin \\ UIN Sunan Gunung Djati Bandung \\ Email: msolahudin@uinsgd.ac.id \\ Ecep Ismail \\ UIN Sunan Gunung Djati Bandung \\ Email: ismailecep27@uinsgd.ac.id \\ Irwan Abdurrohman \\ UIN Sunan Gunung Djati Bandung \\ Email: irwanabdurrohman@uinsgd.ac.id
}

\begin{abstract}
On the one hand, in the environment of the Pesantren salaf community, a kind of environment and tradition is formed which shows its unique, even unique characteristics, which are only understood by the community. Gus Dur, in this case, stated that the Pesantren salaf community is a community that has its own subcultural in the middle of society with the complexity of the problems in it. But on the other hand, there is a very rapid development of science and technology, so it demands pesantren salaf to make changes to adjust to the times, both in terms of the education system, the boarding school environment, institutions, leadership patterns, and others. Therefore, the study contained in the title "Pesantren Salaf: Social Change and Sublimation of Identity (Pesantren Model in West Java)", is very important to be carried out.

The purpose of this study is none other than to find the concept of changes that occur in Pesantren salaf in West Java. For more details, they are: 1) uncovering the factors that drive changes in pesantren in West Java; 2) reveal pesantren's efforts in facing the challenges of the times, and 3) find forms of changes that occur in the Pesantren salaf in West Java.

This research departs from a thought that social change will occur due to four things. First, Evolution. This theory states that humans as part of a cultured society will naturally develop gradually from simple forms to complex and perfect stages. Second, Conflict. This theory strongly believes that change will only occur if there is conflict. Third. Functional Theory. Social change occurs because of the disharmony between cultural elements. Fourth, Cycle Theory. Social change by itself will occur and cannot be controlled.

The method used in this research is descriptive. In the process, the data is collected and compiled. After the data is collected and arranged in such a way, the authors analyze it and provide interpretation, with a qualitative approach. So that it is expected to be able to uncover the realities of the Pesantren salaf which are changing in the community. The results of the study stated that the Pesantren salaf can adapt well to social change by bringing up certain identities. This shift in identity needs to be examined and studied through the theory of action put forward by Max Weber. First, zweckrational. This theory is known as rational-purpose. In doing something always with a good and accurate calculation. Second, wertrational or rational-values. The involvement of the subject is directly involved in matters of absolute importance. The four traditionalists. This theory of action rests on established and established customs or traditions. Traditionalist theories respect existing authority.
\end{abstract}

Keywords:

Pesantren Salaf, Social Change, Sublimation of Identity

Abstrak

Di satu sisi, dalam lingkungan masyarakat pesantren salaf, terbentuk semacam lingkungan dan tradisi yang khas yang menunjukkan kesantriannya, bahkan menjadi ciri khas, yang hanya difahami oleh komunitasnya saja. Gus Dur dalam hal ini menyatakan bahwa komunitas pesantren salaf pada dasarnya adalah sebuah komunitas yang memiliki subkultural tersendiri di tengah masyarakat dengan kompleksitas persoalan yang ada di dalamnya. Tetapi pada sisi lain, terdapat perkembangan ilmu pengetahuan dan teknologi yang sangat cepat, sehingga menuntut pesantren salaf untuk mengadakan perubahan agar menyesuaikan dengan perkembangan zaman, baik dari segi sistem pendidikan, 
lingkungan kepesantrenan, kelembagaan, pola kepemimpinan dan lainnya. Oleh karenanya, kajian yang tertuang dalam judul "Pesantren Salaf: Perubahan Sosial dan Sublimasi Identitas (Model Pesantren di Jawa Barat)", menjadi sangat penting untuk dilaksanakan.

Tujuan penelitian ini tidak lain untuk menemukan konsep perubahan yang terjadi pada pesantren-pesantren Salaf di Jawa Barat. Untuk lebih rincinya yaitu: 1) mengungkap faktor-faktor yang mendorong terjadinya perubahan pada pesantren-pesantren di Jawa Barat; 2) mengungkap upaya pesantren dalam menghadapi tantangan perkembangan zaman; dan 3) menemukan bentuk-bentuk perubahan yang terjadi pada pesantren salaf di Jawa Barat.

Penelitian ini berangkat dari sebuah pemikiran bahwa perubahan sosial akan terjadi karena empat hal. Pertama, Evolusi. Teori ini menyatakan bahwa manusia sabagai bagian dari masyarakat yang berkebudayaan dengan sendirinya akan mengalami perkembangan secara bertahap dari bentuk yang sederhana hingga pada tahap yang komplek dan menjadi sempurna. Kedua, Konflik. Teori ini sangat meyakini bahwa perubahan hanya akan terjadi apabila konflik itu ada. Ketiga. Teori Fungsional. Terjadinya perubahan sosial karena adanya ketidak selarasan antar unsur-unsur kebudayaan. Keempat, Teori Siklus. Perubahan sosial dengan sendirinya akan terjadi dan tidak dapat dikendalikan.

Metode yang digunakan dalam penelitian ini adalah metode deskriptif. Dalam prosesnya data dikumpulkan dan disusun. Setelah data terkumpul dan disusun sedemikian rupa, penulis menganalisisnya dan memberi penafsiran, dengan pendekatan kualitatif. Sehingga diharapkan dapat mengungkap dengan sesungguhnya realitas pesantren salaf yang mengalami perubahan di masyarakat.

Hasil penelitian menyatakan bahwa pesantren salaf dapat beradaptasi dengan baik terhadap perubahan sosial dengan memunculkan identitas tertentu. Pergeseran identitas ini perlu dicermati dan dipelajari melalui teori tindakan yang dikemukakan Max Weber. Pertama, zweckrational. Teori ini dikenal dengan istilah rasional-tujuan. Dalam mengerjakan sesuatu selalu dengan perhitungan yang baik dan akurat. Kedua, wertrational atau rasional-nilai. Keterlibatan subjek terlibat langsung dalam persoalan-persoalan penting yang mutlak. Keempat tradisionalis. Teori tindakan yang satu ini menyandarkan pada kebiasaan atau tradisi yang sudah ada dan mapan. Teori tradisionalis menghormati otoritas yang ada.

\author{
Keywords: \\ Pesantren Salaf, Perubahan Sosial, Sublimasi Identitas
}

DOI: http://dx.doi.org/10.15575/saq.v4i2.7736

Received: 2020-01-28; Accepted: 2020-01-28 ; Published: 2020-01-29

\section{A. Pendahuluan}

Pondok pesantren mempunyai akar sejarah yang panjang, sekalipun pondok pesantren besar yang ada sekarang hanya dapat dilacak asal-usulnya sampai akhir abad ke-19 atau awal abad ke-20. Karenanya dalam hal ini, Dhofier telah membuat peta pondok pesantren-pondok pesantren di Jawa dari abad 19 dan 20, khususnya di Jawa Timur, Jawa Tengah, dan Jawa Barat. ${ }^{1}$ Melihat sejarahnya yang sudah tua dan perkembangannya yang luas, serta apresiasi masyarakat yang sangat mendukung, dapat dipahami bahwa pesantren memiliki pengaruh yang besar terhadap masyarakat sekitarnya. Hal tersebut dibuktikan dengan pernyataan Kartodirdjo bahwa banyak peristiwa sejarah abad ke-19 yang menunjukkan betapa besar pengaruh pondok pesantren dalam memobilisasi masyarakat pedesaan untuk aksi-aksi protes terhadap

1Zamakhsyari Dhofier, Tradisi Pesantren (Jakarta: LP3ES, 1985), 3. masuknya kekuasaan birokrasi kolonial di pedesaan. $^{2}$

Sebagai sebuah lembaga, pesantren tradisional yang ada di pedesaan yang lebih dikenal dengan pesantren salaf, memiliki peranan penting dalam pembentukan budaya bangsa Indonesia. Ajaran kepesantrenan telah merubah perilaku dan budaya masyarakat, terutama ajaran akhlak, tuntunan dan etika baik dalam ibadah maupun dalam bermasyarakat.

KH Achmad Sahid Jauhari berpendapat bahwa peran pesantren di masa lampau sangat besar terhadap kebudayaan bangsa. Kehadiran alumni pesantren ditengah-tengah masyarakat telah memberi warna tersendiri dan dirasakan manfaatnya, baik ditingkat lokal, regional, nasional maupun internasional. Ilmu pengetahuan yang mereka terima dari

2Sartono Kartodirdjo, Protest Movement in Riyayi Dalam Masyarakat Jawa (Kualalumpur: Oxford University Press, 1987), 9. 
pesantren sangat cukup untuk bekal hidup dan berjuang di masyarakat. ${ }^{3}$ Tempat perjuangan dan pengabdiannya adalah mushala-mushala dan masjid-masjid kampung. Mushala dan masjid menjadi sentral pembelajaran keislaman yang efektif pada saat itu.

Tidak mengherankan, meskipun Belanda telah menjajah Indonesia selama 3,5 abad, masyarakat muslim meningkat signifikan. Diperkirakan, saat penjajah datang ke nusantara, penduduk yang memeluk Islam hanya 20\%. Setelah Indonesia merdeka, penduduk muslim berkembang pesat menjadi $95 \%$. $^{4}$

Oleh karenanya, pesantren salaf memiliki peran yang luar biasa dalam pembangunan kebudayaan di masa depan. Institusi ini mengutamakan peran kyai dalam segala hal, termasuk dalam menentukan arah kebijakan pesantren. Sebagai lokomotif pesantren, kyai adalah pemimpin seluruh elemen yang ada di pesantren. Bersama para santrinya, kyai menjadi tokoh yang kukuh dalam melestarikan Islam tradisional di satu sisi dan melakukan penyesuaian diri terhadap perubahanperubahan sosial sebagai tuntutan situasi dan kondisi di sisi lain. ${ }^{5}$

Tuntutan perubahan merupakan sebuah keniscayaan yang memaksa pesantren berada pada situasi yang rumit. Tantangan terbesar pesantren saat ini adalah berkembang pesatnya kebudayaan karena pengaruh globalisasi. Keadaan ini telah berdampak besar pada perubahan budaya, sosial, ekonomi, hukum dan politik.

Pesantren salaf dengan performa tradisionalnya, memungkinkan tergerus oleh pengaruh globalisasi yang lebih mengedepankan kemodernan. Beberapa kasus di berbagai daerah telah menjadi bukti sahih

3http://www.nu.or.id/post/read/13817/problematikapesantren-salaf-masa-kini, diakses 12 Oktober 2017

4http://www.nu.or.id/post/read/13817/problematikapesantren-salaf-masa-kini

5 M. Murtadho, "Pesantren Salaf dan Perubahan Sosial (Studi Kasus Pesantren Salaf Al Anwar Sarang Rembang)", EDUKASI, Volume 10, Nomor 1, JanuariApril (2012), 3-4. bahwa pesantren salaf harus bergegas pada arah penyesuaian diri.

Pesantren Lirboyo misalnya, menjadi salah satu pesantren tradisional yang menghadapi tantangan globalisasi. Pesantren yang didirikan tahun 1910 ini merupakan pesantren salaf terbesar di pulau jawa dengan ribuan santrinya. Belakangan pesantren ini diisukan telah berubah menjadi pesantren berhaluan LDII (Lembaga Dakwah Islam Indonesia) yang kemodernan. Akibatnya, banyak orangtua calon santri yang urung mendaftarkan anaknya untuk nyantri ke pesantren Lirboyo. Berita yang tidak bisa dipertanggungjawabkan ini merugikan pesantren. Untuk mengklarifikasi informasi tersebut, KH Abdul Aziz Mansur menyatakan bahwa pesantren Lirboyo akan tetap dan selamanya berhaluan ahl al-sunnah wa aljama'ah. Beliau pun mengakui banyak pesantren salaf yang gulung tikar, ada yang menjelma menjadi perguruan tinggi, bahkan ada yang jadi kos-kosan. Namun Pesantren Lirboyo akan tetap menjalankan sistem salaf seperti sebelumnya. ${ }^{6}$

Selain pesantren Lirboyo, Ahsanun Naseh $\underline{\text { Khudori }^{7}}$ menuliskan artikelnya bahwa Pondok Pesantren Ma'hadul 'ilmi Wal'Amal (MIA) yang terletak Tulungagung pun merasakan dampak yang mirip sama dari modernisasi. Pada Pertemuan alumninya terungkap, santri yang mondok di pesantren tersebut mengalami penurunan drastis. Beberapa penyebab kemerosotan kuantitas santri antara lain adanya keluhan dari para orangtua santri terhadap perkembangan pesantren. Sebagian besar orangtua santri tersebut merupakan lulusan pesantren MIA. Karenanya mereka sangat merasakan adanya kemerosotan kuantitas santri tertsebut.

Naseh Khudori kemudian mengutip pernyataan salah satu santri MIA tertua, yaitu Tarji, yang berpendapat bahwa mundurnya pesantren salaf karena dua faktor, eksternal

6http://www.muslimedianews.com/2015/05/ponpeslirboyo-berubah-haluan-jadi-ldii.html, diakses 6 Oktober 2017

7 https://www.kompasiana.com/ di akses Oktober 2017 
dan internal. Pada faktor eksternal, masyarakat sudah tidak percaya pada pesantren salafiyah karena tidak marketable, tidak ada jaminan untuk masa depan. tidak ada soft skill yang dimiliki santri saat mondok, yang menyebabkan santri tidak siap dalam menghadapi kehidupan luar pondok. Banyak alumnus santri memilih menjadi Tenaga Kerja Indonesia (TKI), pengurus masjid, tukang adzan, tukang khutbah, guru TPQ dan guru madrasah Diniyah. Faktor internalnya yaitu sistem pendidikan pesantren salafiyah yang merosot dan turunnya semangat belajar santri. ${ }^{8}$

Pada persoalan yang sama, Rahmat Petuguran juga menyatakan, bahwa beberapa pesantren di Cianjur telah gulung tikar, seperti pesantren Al-Irfan, pesantren Gelar, pesantren Ciharashas, dan pesantren Darul Fallah. Masalahnya sama, yaitu kurang peminat. ${ }^{9}$

Eksistensi pesantren salaf yang terus tergerus oleh modernisasi ini perlu mendapatkan perhatian serius dari semua pihak. Sebagai sokoguru pembangunan karakter bangsa, pesantren salaf sejatinya mendapatkan sokongan khusus, dari dunia akademisi dan pemerintah. Sebab, tantangan yang dihadapi oleh pesantren salaf semakin besar, kompleks dan mendesak sebagai akibat semakin meningkatnya kebutuhan pembangunan dan kemajuan ilmu pengetahuan dan teknologi. Tantangan ini menyebabkan terjadinya pergeseran dan perubahan, baik pada nilai, lingkungan pesantren, sistem pendidikan, kelembagaan, pola kepemimpinan, dan lainnya. Di Jawa Barat misalnya, perubahan di lingkungan pesantren salaf telah terjadi. Banyak faktor yang menyebabkan terjadinya perubahan di lingkungan pesantren salaf tersebut, baik dari dalam atau dari luar pesantren.

Dengan demikian, di satu sisi, dalam lingkungan masyarakat pesantren salaf, telah terbentuk imij tentang pesantren yang erat hubungannya dengan kitab kuning dan penguasaan bahasa Arabnya. Lebih dari itu

8 https://www.kompasiana.com/ di akses Oktober 2017.

9http://portalsemarang.com/tantangan-terkinipesantren-salaf/ diakses Oktober 2017 terkadang tamatan pesantren salaf dianggap sebagai calon tokoh agama yang menguasai ilmu agama yang tinggi. Bahkan di lingkungan pesantren salaf ditunjukkan kesantrian mereka, sehingga terbentuk semacam lingkungan dan tradisi yang khas dan menjadi ciri yang khas, yang hanya difahami oleh komunitasnya saja. Gus Dur dalam hal ini menyatakan bahwa komunitas pesantren salaf pada dasarnya adalah sebuah komunitas yang memiliki subkultural tersendiri di tengah masyarakat dengan kompleksitas persoalan yang ada di dalamnya. ${ }^{10}$

Pada sisi lain, terdapat perkembangan ilmu pengetahuan dan teknologi yang sangat cepat, sehingga menuntut pesantren salaf untuk mengadakan perubahan agar dapat menyesuaikan dengan keadaan yang ada, baik dari segi sistem pendidikan, lingkungan kepesantrenan, kelembagaan, pola kepemimpinan dan lainnya.

Oleh karena itu, kajian terhadap persoalan ini menjadi sangat urgen untuk dilaksanakan. Kajian ini tertuang dalam judul "Pesantren Salaf: Perubahan Sosial dan Sublimasi Identitas (Model Pesantren di Kabupaten Tasikmalaya Jawa Barat)".

\section{B. Pesantren Salaf}

Istilah "pesantren" berasal dari kata 'santri' mendapat tambahan awalan 'pe' dan akhiran 'an' yang menunjukkan tempat. Pesantren berarti tempat para santri. ${ }^{11}$ Ikatan kata santri berasal dari suku kata sant (manusia baik) dan tra (suka menolong), sehingga kata pesantren dapat berarti tempat pendidikan manusia baikbaik. C.C. Berg berpendapat bahwa istilah tersebut dari shastri (bahasa India) yang dalam bahasa India berarti orang yang tahu buku-buku suci agama Hindu atau sarjana ahli kitab suci agama Hindu. Kata shastri berasal

10 Gus Dur, Menggerakan Tradis: Esei-esei Pesantren (Yogyakarta: LKiS, 2001), 2-3.

11 Soegarda Poerkawatja, Ensiklopedia Pendidikan (Jakarta: Gunung Agung, 1976), 15. 
dari shastra, yang berarti buku-buku suci atau buku-buku tentang ilmu pengetahuan. ${ }^{12}$

Adapun kata "salaf" secara bahasa berarti sesuatu yang mendahului atau orang yang mendahului. $^{13}$ Term salafi atau salafiyah merupakan penisbatan kepada golongan yang menganut faham generasi masa lalu atau pengikut generasi pertama muslim yang shaleh (al-salaf al-shâlih). ${ }^{14}$ Dalam Islam khususnya di Indonesia, penggunaan term "salafiyah" atau sering juga digunakan "salaf" saja, setidaknya menunjuk dua golongan: pertama, golongan yang menganut paham "Islam yang murni" dan berusaha memurnikan ajaran Islam dari bid'ah dan khurafat; faham ini merupakan wacana dan gerakan pemikiran yang bersifat ideologi keagamaan, kedua, golongan yang mewarisi tradisi-tradisi keilmuan dengan pengajaran model halaqah dari generasigenerasi awal Islam dan atau abad pertengahan. ${ }^{15}$ Penggunaan istilah salaf dalam tulisan ini, dimaksudkan untuk menunjukkan golongan kedua.

Secara terminologis, pondok pesantren salaf adalah lembaga pendidikan Islam khas

12 Jasa Ungguh Muliawan, Pendidikan Islam Integratif; Upaya Mengintegrasikan Kembali Dikotomi Ilmu dan Pendidikan Islam (Yogyakarta: Pustaka Pelajar, 2005), 155.

13 Tim Prima Pena, Kamus Lengkap Bahasa Indonesia, (tk.: Gitamedia Press, tt.), 566. Dalam referensi lainnya, kata salaf (سَّلَف) dengan bentuk jamak

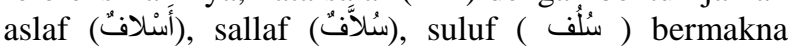
setiap pendahulu yakni ayah, kakek, nenek moyang dan kerabat dalam segi usia dan keutamaan. Salaf adalah setiap amal saleh yang dilakukan di masa lalu; atau apa yang telah lalu dari harga barang yang dijual. Dalam jual beli atau muamalah salaf berarti hutang yang tidak ada manfaatnya pada muqradh fih. https://www.alkhoirot.com/beda-pondok-modern-danpesantren-salaf/\#2, 2. Di akses pada tgl. 01/07/2018, pukul 7:31. Sedangkan secara literal, kata salaf dalam istilah pesantren adalah kuno, klasik, dan tradisional, sebagai kebalikan dari pondok modern, kholaf, atau ashriyah. https://www.alkhoirot.com/beda-pondokmodern-dan-pesantren-salaf/\#2, 3. Di akses pada tgl. 01/07/2018, pukul 7:31

14 Arief Subhan, Lembaga Pendidikan Islam Indonesia Abad Ke-20: Pergumulan antara Modernisasi dan Identitas (Jakarta: Kencana, 2012), 281.

15 Azyumardi Azra, Pendidikan Islam; Tradisi dan Modernisasi di Tengah Tantangan Milenium III (Jakarta: Kencana, 2012), 129.
Indonesia (indigenous) yang diasuh oleh kyai kharismatik dengan tujuan untuk mendalami Ilmu-ilmu agama yang merujuk kepada kitabkitab Islam klasik, dengan masa belajar yang disesuaikan dengan banyaknya kitab klasik yang dipelajari. ${ }^{16}$ Dalam proses pengajaran kitab-kitab Islam klasik tersebut, seorang kyai menggunakan metode-metode:

a. Sorogan, yaitu pelaksanaan pembelajaran dengan cara santri menghadap kyai seorang demi seorang dengan membawa kitab yang dipelajarinya berdasarkan tingkatannya. ${ }^{17}$ Atau dapat juga disebut sebagai pengajian yang merupakan permintaan dari seorang atau beberapa orang santri kepada kyainya untuk diajarkan kitab tertentu. Pengajian sorogan biasanya hanya diberikan kepada santri-santri yang cukup maju, khususnya yang berminat hendak menjadi kyai. ${ }^{18}$

b. Bandongan, yaitu pelaksanaan pembelajaran dengan metode dimana para santri duduk mengelilingi kyai. Kyai membacakan kitab, santri menyimak dan membuat catatan sendiri.

c. Muhawarah, yaitu pelaksanaan pembelajaran dalam pondok pesantren dengan latihan bercakap-cakap dengan bahasa arab Arab yang diwajibkan oleh pondok pesantren kepada para santri.

d. Mudzakarah, yaitu pelaksanaan pembelajaran di dalam pondok dengan cara mengadakan pertemuan ilmiah, yang bisa dilaksanakan antara kyai dengan para santri dan antara santri dengan santri.

16 Haidar Putra Daulay, Sejarah Pertumbuhan dan Pembaruan Pendidikan Islam di Indonesia (Jakarta: Kencana Prenada Media Grup, 2007), 57. Sedangkan menurut Zamakhsyari Dhofier, pesantren salaf adalah lembaga pesantren yang mempertahankan pengajaran kitab-kitab Islam klasik (salaf) sebagai inti pendidikan. Sistem madrasah ditetapkan hanya untuk memudahkan sistem sorogan, yang dipakai dalam lembaga-lembaga pengajian bentuk lama, tanpa mengenalkan pengajaran pengetahuan umum. www.masjidjami-alittihadcitraindah.com/

17 Haidar Putra Daulay, Sejarah Pertumbuhan dan Pembaruan Pendidikan Islam di Indonesia, 57.

18 Nurcholish Madjid, Bilik-Bilik Pesantren: Sebuah Potret Perjalanan, (Jakarta: Paramadina, 1997), 28. 


\section{Perubahan Sosial}

Pesantren salaf yang menekankan pendidikan dengan pendekatan tradisi lama, mengajarkan kitab-kitab karya ulama terdahulu, menerima tantangan zaman yang telah berubah dan menuntut adanya penyesuaian diri.

Tuntutan penyesuaian diri ini memaksa pesantren untuk melihat kenyataan sosial yang mengalami perubahan di berbagai bidang. Menurut teori, perubahan sosial akan terjadi karena empat hal. ${ }^{19}$ Pertama, evolusi. Teori evolusi menyatakan bahwa manusia sabagai bagian dari masyarakat yang berkebudayaan dengan sendirinya akan mengalami perkembangan secara bertahap dari bentuk yang sederhana hingga pada tahap yang komplek dan menjadi sempurna. Kebudayaan yang sudah dibentuk oleh manusia generasi terdahulu, tidak bisa dipertahankan. Waktu yang terus bergulir dan manusia secara turuntemurun melahirkan generasi berikutnya, tidak akan dapat memahami kebudayaan nenek moyangnya secara utuh. Yang terjadi, sangat mungkin kebudayaan baru muncul menggantikan tradisi sebelumnya, budaya yang lebih baik, sesuai dengan keadaan zaman yang sedang dijalani.

Kedua, Teori Konflik. Teori ini sangat meyakini bahwa perubahan hanya akan terjadi apabila konflik itu ada. Konflik dalam kehidupan masyarakat yang terus berlangsung lama akan berdampak pada perubahan yang dengan sendirinya terjadi.

Ketiga. Teori Fungsional. Terjadinya perubahan sosial karena adanya ketidak selarasan antar unsur-unsur kebudayaan. Unsur kebudayaan yang satu berubah sangat signifikan dan cepat. Sedangkan unsur kebudayaan yang lainnya kesulitan mengikuti ritme perubahan dan cenderung konstan. Pada akhirnya, antar unsur kebudayaan memiliki kualitas yang berbeda, yang satu baru dan yang lainnya lama. Unsur kebudayaan baru dan lama ini akan memunculkan kesenjangan

19 M. Murtadho, Pesantren Salaf dan Perubahan Sosial, Jurnal Penelitian Pendidikan Agama dan Keagamaan, 3. diantara unsur-unsur kebudayaan tersebut, Cultural Lag.

Keempat, Teori Siklus. Perubahan sosial dengan sendirinya akan terjadi dan tidak dapat dikendalikan. Maju dan mundurnya sebuah kebudayaan merupakan hal yang harus dimaklumi. Bergulirnya waktu memaksa segala sesuatu yang ada dalam kehidupan ini akan berubah. Kebudayaan akan mengikuti siklus perubahan yang sesuai dengan zaman di masanya. Siapapun tidak bisa memaksakan kehendak untuk mempertahankan tradisi sebelumnya pada zaman berikutnya. Perubahan sosial di masyarakat tidak dapat dihindari. Keadaan yang berubah ini harus bisa diterima dan menjadi bagian dari perubahan itu sendiri.

Keempat teori tersebut cukup memadai untuk melihat pesantren salaf saat ini. Dari sisi usia, pesantren salaf telah mengalami fasefase kehidupan yang panjang dan melihat perubahan yang terjadi di masyarakat pada tiap generasinya. Dan pada tiap generasi itu, memiliki pandangan yang berbeda dari generasi sebelumnya. Kondisi ini akan menjadi konflik yang memaksa generasi baru mencitrakan diri dengan cara hidupnya yang berbeda dengan sebelumnya dan membangun tradisi dan kebudayaan baru.

Pesantren tidak hanya mengalami perubahan kultural, akan tetapi juga mengalami pergeseran identitas. Pesantren Salaf yang sarat dengan unsur-unsur lama yang tradisional, bisa jadi menerima unsurunsur kebaruan dalam bidang pendidikan, ekonomi, dan kebudayaan. Pergeseran identitas ini perlu dicermati dan dipelajari melalui teori tindakan yang dikemukakan Max Weber.

Max Weber ${ }^{20}$ menjelaskan empat teori tindakan; Pertama, zweckrational. Dalam bahasa Indonesia, teori ini dikenal dengan istilah rasional-tujuan. Dalam mengerjakan sesuatu selalu dengan perhitungan yang baik dan akurat. Sarana dan prasarana yang memang dibutuhkan dan tujuan-tujuan

20 Tom Campbell, Tujuh Teori Sosial: sketsa, Penilaian, Perbandingan, kanisius, (Yogyakarta: Kanisius, 2001, 208-209. 
diperjelas. Dengan cara mempertegas tujuan dan masuk akal, apapun yang dikerjakan akan mendapatkan hasil yang memuaskan. Tidak hanya itu, ini adalah bentuk pemikiran yang logis, ilmiah dan ekonomis

Kedua, wertrational atau rasional-nilai. Keterlibatan subjek terlibat langsung dalam persoalan-persoalan penting yang mutlak. Yang lebih dikejar adalah nilainya, sedangkan sarananya tidak terlalu diperhatikan. Hitungan secara rasional muncul untuk menemukan sarana-sarana yang dibutuhkan saja dan tujuan-tujuan yang dinilai. Dengan kata lain, sarana-saran dan tujuan ditentukan oleh nilainilai. Moral yang mengagumkan hanya akan didapat dengan sarana yang baik.

Ketiga, tipe ideal untuk tindakan efektif atau emosional. Teori ini menjelaskan betapa perasaan-perasaan sangat mendominasi tingkahlaku. Tindakan yang dilakukan oleh teori ini tidak bersandarkan pada rasionalitas, tapi lebih kepada emosional. Oleh karena itu, hasil yang diperolehnya tentu tidak masuk dalam kategori ilmiah.

Keempat tradisionalis. Teori tindakan yang satu ini menyandarkan pada kebiasaan atau tradisi yang sudah ada dan mapan. teori tradisionalis menghormati otoritas yang ada.

Teori Max Weber di atas ditujukan untuk manusia. Tindakan-tindakan manusia dapat dipahami melalui empat tindakan di atas. Kyai merupakan tokoh sentral dalam tradisi pesantren salaf. Hampir semua pesantren salaf, dapat dipastikan, pengasuh sekaligus pemiliknya adalah Kyai dan keluarganya. Teori weber ini, dapat membantu mengungkap tindak-tanduk seorang kyai dalam men-drive atau memimpin pesantrennya. Hal ini dapat membantu mengungkap informasi mengenai perubahan-perubahan yang terjadi pada pesantren salaf dan pergeseran identitas akibat bergesekan dengan modernisasi.

\section{Sublimasi Identitas}

Secara kebahasaan, kata "sublimasi" berarti perubahan ke arah satu tingkat lebih tinggi. ${ }^{21}$ Kata ini sering digunakan bidang psikologi dan kimia dengan makna yang berbeda. Dalam psikologi, istilah sublimasi dimaknai sebagai "redirecting of unacceptable impulses: the channeling of impulses or energies regarded as unacceptable, especially sexual desires, toward activities regarded as more socially acceptable, often creative activities" 22 (mengarahkan kembali impuls/dorongan batin yang tidak dapat diterima, yakni: menyalurkan impuls atau energi yang dianggap tidak dapat diterima, terutama hasrat seksual, terhadap aktivitas yang dianggap sebagai kegiatan yang lebih dapat diterima secara sosial, dan sering kali bersifat kreatif). Dengan ungkapan yang lebih singkat, sublimasi dalam terminologi psikologi adalah "usaha pengalihan hasrat yang bersifat primitif ke tingkah laku yang dapat diterima oleh norma masyarakat.,23

Sedangkan dalam bidang kimia, sublimasi didefinisikan sebagai "chemical conversion: a process in which a substance is converted directly from a solid to a gas or from a gas to a solid without an intermediate liquid phase $^{, 24}$ (konversi kimia, yakni: suatu proses di mana suatu zat diubah langsung dari padatan menjadi gas atau dari gas menjadi padat tanpa fase cair antara). Dalam kamus Bahasa Indonesia, sublimasi dalam kimia bermakna "perubahan langsung bentuk padat suatu zat menjadi uap tanpa melalui bentuk cair." ${ }^{25}$ Selain perubahan wujud suatu zat dari padat ke gas atau sebaliknya, istilah sublimasi juga digunakan untuk menyebutkan salah satu metode pemisahan campuran kimia, yaitu dengan cara memanaskan zat padat yang

21Tim Redaksi Kamus Bahasa Indonesia, Kamus Bahasa Indonesia (Jakarta: Pusat Bahasa Departemen Pendidikan Nasional, 2008), 1535.

22Microsoft Corporation, Encarta Dictionaries, Microsoft® Encarta $₫ 2009$.

23Tim Redaksi Kamus Bahasa Indonesia, Kamus Bahasa Indonesia, 1535.

24Microsoft Corporation, Encarta Dictionaries, Microsoft® Encarta $₫ 2009$.

25Tim Redaksi Kamus Bahasa Indonesia, Kamus Bahasa Indonesia, 1535. 
terlarut pada zat padat sehingga zat padat yang akan diambil akan berubah menjadi gas. Gas yang dihasilkan kemudian ditampung lalu didinginkan. Syarat pemisahan campuran dengan cara sublimasi ini yaitu partikel yang bercampur harus memiliki perbedaan titik didih yang besar sehingga dapat menghasilkan uap dengan tingkat kemurnian yang tinggi.

Adapun kata "identitas" berasal dari bahasa Inggris "identity" yang antara lain berarti: "the name or essential character that identifies somebody or something" 26 (nama atau ciri penting yang dapat mengenali seseorang atau sesuatu). Dalam Kamus Bahasa Indonesia, identitas diartikan sebagai "ciri-ciri atau keadaan khusus seseorang atau suatu benda," atau dikatakan secara singkat sebagai "jatidiri.", Dengan demikian, identitas merujuk pada sifat-sifat yang melekat pada diri seseorang atau suatu benda yang menjadi ciri keberadaannya. Kata ini juga dapat digunakan untuk mencirikan suatu kelompok atau lembaga. Suku bangsa, agama, organisasi masyarakat dan partai politik, misalnya, memiliki identitas atau jatidirinya masingmasing. Demikian juga pesantren sebagai sebuah lembaga pendidikan keagamaan di Indonesia tentunya juga memiliki identitas atau jatidiri tersendiri.

Dalam penelitian ini, yang dimaksud dengan sublimasi identitas adalah perubahan yang terjadi dalam sebuah pesantren dari suatu keadaan awal yang khas dan tetap kepada keadaan baru yang berbeda dari semula sebagai konsekuensi dari keinginan mengikuti tuntutan dan perkembangan zaman. Keadaan baru yang khas tersebut kemudian dibakukan dan bersifat tetap, sehingga pada gilirannya ia menjadi jatidirinya. Apakah hal tersebut terjadi pada pesantren-pesantren salaf yang ada di Indonesia? Penelitian ini akan berupaya menjawabnya dengan memotret tiga pesantren besar yang ada di Kabupaten Tasikmalaya Jawa Barat, yaitu: Pondok Pesantren

26Microsoft Corporation, Encarta Dictionaries, Microsoft $®$ Encarta ${ }^{\circledR} 2009$.

27Tim Redaksi Kamus Bahasa Indonesia, Kamus Bahasa Indonesia, 567.
Sukamanah, Pondok Pesantren Cipasung, dan Pondok Pesantren Miftahul Huda Manonjaya.

\section{E. Upaya Pondok Pesantren Sukamanah Dalam Menghadapi Perubahan Sosial}

Adapun upaya-upaya yang dilakukan Pondok Pesantren Sukamanah adalah sebagai berikut:

\section{Sistem Pendidikan Pondok Pesantren Sukamanah}

\section{a. Sistem Klasikal}

Pada tahun 1950 K.H. Muh. Fuad Muhsin dan K.H. Abdul Aziz, adik kandung K.H. Zainal Musthafa, dan tokoh-tokoh lainnya mulai membangun kembali Pesantren Sukamanah setelah pertempuran melawan penjajah, dengan pengajian bulanan masyarakat sekitar dan santri dari kalangan pemuda Kampung Sukamanah, dengan menggunakan bangunan masjid dan asrama peninggalan K.H. Zainal Musthafa yang telah diperbaiki alakadarnya secara gotong royong oleh masyarakat Sukamanah. Dari hari ke hari, mulailah berdatangan santri-santri dari luar daerah. Sekalipun tidak terlalu banyak jumlahnya, telah menampakkan gairah kehidupan kembali pesantren. Sistem pengajaran yang diterapkan yaitu sistem klasikal: santri ditempatkan pada kelas tertentu sesuai dengan tingkat kemampuan yang dimilikinya (tidak berdasarkan tingkatan sekolah) yang diukur melalui tes klasifikasi bagi santri baru, yang dilaksanakan di awal tahun pelajaran.

\section{Pendidikan Formal}

Selain kegiatan kepesantrenan yang lebih dikenal Pesantren Sukahideng-Sukamanah, Pada tanggal 17 Agustus 1959 didirikan pula "Yayasan K.H. Zainal Musthafa Sukamanah" yang bertujuan untuk melanjutkan perjuangan pahlawan nasional K.H. Zainal Musthafa dalam rangka menjunjung tinggi martabat kalimat Allah melalui pendidikan dan pengajaran. Yayasan ini mulai mendirikan lembaga-lembaga formal di lingkungan kedua pesantren tersebut, MI dan SMP yang sudah ada namanya dilengkapi menjadi "Madrasah Ibtidaiyah K.H. Zainal Musthafa Sukahideng" dan "SMP K.H. Zainal Musthafa Sukamanah". 
Pada tahap berikutnya, didirikanlah K.H. Zainal Musthafa Sukamanah, dan terus berkembang dengan didirikannya Pendidikan Guru Agama (PGA) 4 Tahun, PGA 6 Tahun, yang selanjutnya menjadi PGAN (Pendidikan Guru Agama Negeri) Sukamanah, dan dikembangkan lagi menjadi MTsN Sukamanah dan MAN Sukamanah. Sementara SMP dan SMA K.H. Zainal Musthafa Sukamanah tetap berdiri sampai sekarang; begitu pula Madrasah Diniyah, TKA/TPA, dan lembaga pelayanan masyarakat, meliputi Kopontren dan Poskestren. Jadi, setiap santri, selain belajar kitab-ktiab kuning di pesantren dengan mengikuti program klasikal tadi, juga mengikuti pendidikan formal. Jumlah santri Pesantren Sukamanah semakin bertambah dengan berdirinya sekolah-sekolah tersebut. ${ }^{28}$

Pendidikan formal akan mampu melahirkan para intlektual di bidang ilmu pengetahuan dan teknologi. Hal ini merupakan sesuatu yang pada sistem pendidikan pesantren salaf tidak diketemukan. Berdasarkan pengamatan para Kyai, dalam menghadapi era perkembangan zaman seperti sekarang, tamatan pesantren salafiyah murni tanpa pendidikan formal, kurang sesuai dengan kebutuhan masyarakat di era sekarang, meskipun tidak seluruhnya. Dalam arti lain, produk pesantren salafiyah/salaf murni tanpa pendidikan formal, hanya dapat diterima yang mayoritas masyarakatnya santri.

Mengapa Pondok Pesantren Sukamanah tetap menyelenggarakan pendidikan pesantren berbasis salafiyah yang menggunakan sistem klasikal? Menurut KH. Salman, sebagai salah seorang Kyai di Pesantren tersebut, bahwa pesantren salafiyah atau salaf telah terbukti melahirkan banyak ulama yang berkualitas di bidang ilmu agama, yang pada satu sisi keagamaan tidak mampu ditandingi oleh produk sistem pendidikan apapun, termasuk pendidikan formal. Salah seorang alumni pesantren Sukamanah salah satunya adalah saya (begitu menurut tuturan KH. Salman). ${ }^{29}$

28 Tita Rhadiatan Mardiah, dari berbagai sumber http://www.pstkhzmusthafa.or.id/.

29Hasil wawancara penulis dengan KH. Salman pada saat berkunjung ke pesantren Sukamanah.
Tradisi pesantren yang luhur antara lain semangat yang tinggi dalam mencari ilmu agama, hal ini dibuktikan oleh para santri yang datang dari perkampumham yang jauh, yang pada masa lalu harus berjalan kaki dengan bekal seadanya. Keikhlasan dalam beramal, hal ini bukanlah slogan semata, tetapi para santri salafiyah mengimplementasikannya dalam kehidupan.

Jadi menurut penulis, pengadaan pendidikan formal disamping pendidikan pesantren salaf sistem klasikal, bertujuan untuk memberikan keseimbangan dalam kualitas, dan menjawab tantangan yang dibutuhan masyarakat pada era kontemporer ini.

\section{a. Fasilitas}

Fasilitas merupakan penopang kesuksesan suatu lembaga pendidikan dalam menciptakan regenerasi yang berkualitas unggul dalam ilmu dan bakat. Pengadaan fasilitas selalu mengalami perkembangan, seiring dengan bertambahnya santri dan kebutuhannya.

Begitu juga lembaga pondok pesantren seperti pondok pesantren Sukamanah, fasilitas sebagai sesuatu yang urgen keberadaannya. Diantara fasilitas yang dimilikinya yaitu: Masjid, asrama santri, kantor, asrama pengasuh, dapur, gedung sekolah, lapangan, koperasi santri, perpustakaan, laboratorium komputer, laboratorium bahasa, gudang, kamar mandi/wc, dan klinik kesehatan. Fasilitas-fasilitas tersebut berkembang keberadaan dan kualitasnya, senada dengan kebutuhan para santri dan penyesuaian pesantren terhadap kebutuhan sosial dan tuntutan zaman.

\section{b. Ekstrakurikuler}

Pondok Pesantren Sukamanah, selain memiliki kegiatan intrakurikuler, kegiatan ekstrakurikuler pun menjadi andalan dalam mengembangkan bakat dan skil para santri di pesantren ini. Kegiatan ekstrakurikuler yang dimilikinya yaitu :

1. Kajian kitab-kitab kuning (kitab salaf);

2. Pembinaan Tilawatil Qur'an;

3. Latihan berpidato dalam tiga bahasa (Indonesia, Inggris dan Arab);

4. berbahasa Arab dan Inggris sehari-hari;

5. Diskusi dan Penelitian Ilmiah; 
6. Kepramukaan;

7. Pengembangan Olahraga;

8. Pengembangan Seni Drumband, Qashidah dan Marawis;

9. Pengembangan Seni Beladiri;

10. Tahfidhul Qur'an;

11. Pengembangan jurnalistik dan publisistik;

12. Pengembangan Exacta (Lab Skill), Ketrampilan, Wirausaha;

13. Pertanian dan Peternakan; dan

14. Perikanan.

Menurut KH. Salman, bahwa pendidikan ekstrakurikuler dimaksudkan untuk memberikan bekal kepada para santri, agar memiliki satu atau beberapa keahlian yang ditekuni secara profesional, untuk menjawab tuntutan masyarakat yang perkembangannya semakin kompetitif. ${ }^{30}$ Kegiatan ekstrakurikuler tersebut sangat disadari oleh seluruh komponen pesantren, termasuk para wali santri, sehingga kegiatan yang wajib diikuti para santri sesuai bakat dan minatnya tersebut dapat berjalan dengan baik.

Upaya-upaya yang telah dilakukan oleh Pesantren Sukamanah secara teoritispedagogis sangat relevan dengan pendapat Benyamin S. Bloom tentang tujuan pendidikan yang meliputi tiga aspek, yaitu: 1) pengetahuan (cognitive); 2) keterampilan (psychomotor); dan 3) sikap (affective). Dari segi aspek pengetahuan yang diajarkan kepada para santri oleh pesantren Sukamanah, sangat terpadu antara ilmu pengetahuan agama dan ilmu pengetahuan umum melalui penerapan kurikulum perpaduan, yang diadopsi dari Kementerian Agama dan Kementerian Pendidikan Nasional. Hal itu senada dengan apa yang diungkapkan Muslih Usa dalam bukunya, bahwa pendidikan alternatif masa depan adalah sistem yang memadukan antara dua sisi, yaitu pengetahuan agama dan umum, sehingga dalam diri siswa atau santri dapat terintegrasi dua disiplin ilmu yang seringkali bertentangan. Dengan demikian, tidak ada lagi

30Hasil wawancara penulis dengan KH. Salman pada saat berkunjung ke pesantren Sukamanah. dengan apa yang disebut dikotomi
pengetahuan 31

\section{F. Upaya Pondok Pesantren Cipasung Dalam Menghadapi Perubahan Sosial}

Terdapat berbagai upaya yang dilakukan oleh Pondok Pesantren Cipasung dalam mengembangkan pendidikan, sebagai cara dalam mencerdaskan anak bangsa, baik dengan ilmu pengetahuan agama, maupun ilmu pengetahuan umum, untuk menghadapi perubahan sosial yang terjadi, sebagai sunnatullah dalam kehidupan bermasyarakat.

Adapun upaya-upaya yang dilakukan Pondok Pesantren Cipasung tersebut, yaitu:

\section{Pendidikan}

Sebagai langkah antisipasi dari sebuah perubahan yang akan, sedang, dan telah terjadi, Pondok pesantren Cipasung, selain memiliki nama besar karena kiprah tokoh pendirinya, sebanding dengan besarnya kiprah dalam pengembangan pendidikan, yang merupakan tugas utama dari sebuah lembaga pendidikan seperti pesantren.

Diantara beragam kiprah dari sebuah lembaga pendidikan yang dilakukan oleh Pondok Pesantren Cipasung, diantaranya mendirikan:

1. Pondok Pesantren;

2. Majlis Taklim;

3. TK Islam Cipasung;

4. MI 1 dan 2;

5. MTs. Cipasung;

6. SMP Islam Cipasung;

7. SMA Islam Cipasung;

8. MAN Cipasung;

9. SMK Islam Cipasung;

10. SMK Kesehatan;

11. IAIC Cipasung;

12. STIE Cipasung;

13. STTC Cipasung; dan

14. Pascasarjana IAIC.

31Muslih Usa, Pendidikan Islam di Indonesia Dalam Transformasi Sosial Budaya: Antara Cita dan Fakta, (Yogyakarta: Tiara Wacana, 1991), 45. 
Semua lembaga-lembaga pendidikan tersebut berada di bawah koordinasi Yayasan Pesantren Cipasung dengan Akta Notaris Yayasan No. 11 tahun 1967. Dengan tersedianya berbagai pendidikan di Pondok Pesantren, sejak MI sampai Perguruan Tinggi, maka kian hari bertambah pula santri yang berdatangan dari berbagai pelosok persada tanah air, khususnya daerah Jawa Barat dan DKI Jakarta. Hal ini membuktikan bahwa Pondok Pesantren Cipasung dituntut dan diperlukan keberadaannya, terutama dalam mencetak kader Ulama Intelek, dan Intelek Ulama, untuk menghadapi perubahan sosial yang terjadi.

\section{Fasilitas}

Pondok Pesantren Cipasung adalah salah satu lembaga pendidikan yang sangat membutuhkan fasilitas dalam menjalankan misi pendidikannya. Berbagai fasilitas yang tersedia di Pondok Pesantren Cipasung, diantaranya: Masjid, asrama santri, kantor, asrama pengasuh, dapur, sekolahan, lapangan, koperasi santri, perpustakaan, laboratorium komputer, laboratorium bahasa, gudang, kamar mandi/wc, klinik kesehatan, dan Lembaga Pendidikan.

Fasilitas-fasilitas tersebut menjadi penentu dari berbagai aktivitas yang terjadi pada tiap harinya di Pondok Pesantren Cipasung. Bahkan pada fasilitas tertentu, penggunaannya full dua puluh empat jam. Kesempurnaan fasilitas, akan berdampak pula pada kesuksesan atau keberhasilan dari suatu kegiatan. Sebab, kesempurnaan dan kualitas fasilitas, akan berdampak pula pada rasa nyaman atau tidaknya bagi para santri/siswa, yang pada kelanjutannya akan berdampak pula pada fokus dan tidak fokusnya para santri/siswa dalam belajar. Oleh karenanya, fasilitas merupakan hal yang paling awal dilihat oleh calon santri/ siswa, dan calon wali santri/siswa.

Menurut pengamatan penulis, dari hasil survei yang telah dilakukan, berbagai fasilitas yang dimiliki Pondok Pesantren Cipasung, sudah memenuhi syarat sebagai penopang dan penentu kesuksesan dari berbagai kegiatan yang terjadi pada tiap harinya. ${ }^{32}$ Hal itu pulalah sebagaimana yang dikatakan oleh pengurus Pondok Pesantren Cipasung, bahwa para santri sangat "betah" tinggal di pondok. ${ }^{33}$ Rasa "betah" itu menandakan adanya rasa nyaman yang dirasakan oleh para santri. Rasa nyaman sangat erat kemunculannya dengan kualitas berbagai fasilitas yang menyertai para santri/ siswa pada tiap harinya, bahkan dua puluh empat jam selama berada di pondok pesantren Cipasung.

\section{Ekstrakurikuler}

Disamping kegiatan intrakurikuler, pondok pesantren Cipasung juga memiliki berbagai kegiatan ekstrakurikuler. Kegiatan-kegiatan tersebut pada umumnya hampir sama dengan pesantren-pesantren lainnya, namun ada juga beberapa yang berbeda. Diantara kegiatan ekstrakurikuler tersebut yaitu:

1. Kajian kitab-kitab kuning (kitab salaf);

2. Pembinaan Tilawatil Qur'an;

3. Latihan berpidato dalam tiga bahasa (Indonesia, Inggris dan Arab);

4. berbahasa Arab dan Inggris sehari-hari;

5. Diskusi dan Penelitian Ilmiah;

6. Kepramukaan dan LKBB;

7. Pengembangan Olahraga;

8. Pengembangan Seni Drumband, Qashidah dan Marawis;

9. Pengembangan Seni Beladiri (Tapaksuci);

10. Tahfidhul Qur'an;

11. Pengembangan jurnalistik dan publisistik; dan

12. Pengembangan Exacta (Lab Skill).

Kegiatan-kegiatan ekstrakurikuler yang ada di Pondok Pesantren Cipasung di atas, menurut penulis, merupakan pemenuhan aspek psikomotor para santri/ siswa. Aspek ini sangat diperlukan dalam kaitannya dengan kebutuhan para santri/ siswa dalam

32Hasil survei penulis pada saat berkunjung ke pesantren Cipasung, dengan berkeliling pesantren untuk melihat keadaan berbagai fasilitas yang ada.

33Hasil wawancara penulis dengan ketua pengurus (saudara Muhammad), pada saat berkunjung ke pesantren Cipasung. 
mengarungi kehidupan bermasyarakat kelak setelah lulus dari pesantren. Terlebih lagi pada era kontemporer ini, dimana persaingan hidup sangat ketat dan kompetitif. Karenanya, perbaikan dan penyesuaian dari kegiatan ekstrakurikuler harus seiring dan sejalan dengan perkembangan zaman dan tuntutan sosial yang terjadi di masyarakat. Pondok Pesantren Cipasung dalam berbagai kegiatan ekstrakurikulernya, menurut pengamatan penulis, sudah memenuhi standar yang selaras dengan perkembangan dan perubahan sosial yang ada di masyarakat.

\section{G. Upaya Pondok Pesantren Miftahul Huda Manonjaya Dalam Menghadapi Perubahan Sosial}

\section{Program Pendidikan}

Berbeda dengan dua pesantren di atas, yaitu pesantren Sukamanah dan pesantren Cipasung yang memiliki program pendidikan formal sekolah seperti TK, TPA, MI, MTs, MA, SMP, SMA, hingga STAI, Pondok Pesantren Miftahul Huda Manonjaya merupakan Pondok Pesantren Salafi/ Salafiyah, dimana fokus kegiatan pendidikan di pesantren ini, mengkaji kitab-kitab kuning (klasik) saja. Akan tetapi, sistem pendidikan yang dijalankan di pesantren ini, yaitu semi formal yang berjenjang, yang dipandu dengan kurikulum dan silabus yang disusun oleh pendiri pesantren Almarhum KH. Choer Affandy, atau yang lebih akrab dipanggil Uwa Ajengan Manonjaya. Masing-masing jenjang ditempuh selama 3 tahun dengan materi pelajaran sebagai berikut:

\section{a. Tingkat Ibtida}

\begin{tabular}{|c|c|c|}
\hline $\begin{array}{l}\text { Kelas } 1 \\
\text { (Satu): }\end{array}$ & Kelas 2 (dua) & $\begin{array}{l}\text { Kelas } 3 \\
\text { (Tiga) }\end{array}$ \\
\hline Tauhid & Jurumiyah & Shorof \\
\hline Rancang & Safinatunnajja & Kailany \\
\hline Fiqih & Tijan Addaruri & Riyadlul \\
\hline Rancang & Khulashoh & Badi'ah \\
\hline Syahadatain & jilid 1 & Majmu'atul \\
\hline Tarikh & Akhlaq lil & 'Aqidah jilid \\
\hline Rancang & Banain/Banat & $1-2$ \\
\hline Wiridan & jilid 1 & Khulashoh \\
\hline Istighosah & Tasrifan & jilid 2-3 \\
\hline Sholat & Tajwid & Akhlaq lil \\
\hline
\end{tabular}

\begin{tabular}{|l|l|l|}
\hline Fardlu & Bahasa Arab & Banain/Banat \\
Iqro - & jilid 2 & jilid 2-3 \\
Qur'an & Hafalan & Qiyasan \\
Tajwid & Jurumiyah & Hadits \\
Bahasa Arab & Hafalan Juz & Arba'in \\
jilid 1 & 'Amma & Bahasa Arab \\
& & jilid 3 \\
& & Pengulangan \\
& & Jurumiyah \\
& & Hafalan juz \\
& & 'Amma \\
\hline
\end{tabular}

b. Tingkat Tsanawi

\begin{tabular}{|l|l|l|}
\hline Kelas 1 & Kelas 2 & Kelas 3 \\
\hline Alfiyah ibn & Jauhar & Jauhar \\
Malik & Tauhid & Maknun \\
Bajuri jilid 1- & Fathul Mu'in & Khoridatul \\
2 & jilid 1-2 & Bahiyyah \\
Kifayatul & Faro'idl & Fathul Mu'in \\
'Awwam & (Rohbiyah) & jilid 3-4 \\
Tafsir & Mantiq & Waroqot \\
Jalalain & Isti'arah & Latho'iful \\
Riyadlus- & 'Alajul & 'Isyaroh \\
sholihin & Amrod & Kifayatul \\
Kifayatul & Shohih & Akhyar \\
Atqiya & Bukhori jilid & Shohih \\
Pengulangan & 1-2 & Bukhori jilid \\
Shorof & Shohih & 3-4 \\
Kailany & Muslim jilid & Shohih \\
Hafalan & 1 & Muslim jilid \\
Matan & Pengulangan & 2 \\
Alfiyah & Alfiyah & Sirojut- \\
& Hafalan & tholibin \\
& Rohbiyah, & Pengulangan \\
c. Tingkat Ma'had 'Aly & Mantiq \\
\hline Kelas 1 & Kelas 2 & Kelas 3 \\
\hline Ghoyatul & Jam'ul & Jam'ul \\
Wushul & Jawamy jilid & Jawamy jilid \\
'Uqudul & 1 & 2 \\
Juman & 'Uqudul & Fathul Wahab \\
Fathul Wahab & Juman & Asybah \\
Asybah & Fathul Wahab & Wannadzo'ir \\
Wannadzo'ir & Asybah & Bidayatul \\
Bidayatul & Wannadzo'ir & Mujtahid \\
Mujtahid & Bidayatul & Ihya \\
\hline & \multicolumn{2}{|l}{ Hafalan } \\
\hline
\end{tabular}




\begin{tabular}{|l|l|l|}
\hline $\begin{array}{l}\text { Ihya } \\
\text { 'Ulumuddin }\end{array}$ & $\begin{array}{l}\text { Mujtahid } \\
\text { Ihya } \\
\text { 'Ulumuddin }\end{array}$ & 'Ulumuddin \\
\hline
\end{tabular}

Dari masing-masing jenjang pendidikan semi formal yang ditempuh selama 3 tahun oleh para santri dengan materi pelajaran sebagaimana tersebut di atas, meskipun tidak melaksanakan pendidikan formal sekolah seperti dua pesantren di atas (pesantren Sukamanah dan pesantren Cipasung), pesantren Miftahul Huda Manonjaya memiliki "kekhususan" tersendiri, yaitu "penyetaraan status legalitas" dari Kementerian Agama. Meskipun menggunakan kurikulum sendiri yang disusun oleh pendiri pesantren, tetapi pada masing-masing jenjang pendidikan semi formal tersebut mendapatkan penyetaraan status. Dimana untuk tingkat Ibtida' disetarakan dengan tingkat MTs atau SMP, tingkat Tsanawi disetarakan dengan tingkat MA atau SMA, dan untuk tingkat Ma'had 'Aly disetarakan dengan pendidikan S1, dengan tambahan-tambahan program pendidikan ekstrakurikuler yang disesuaikan dengan kebutuhan pada tingkat tersebut. ${ }^{34}$

Salah satu yang menjadi catatan penulis, keistimewaan dari penyetaraan pada masingmasing tingkat tersebut, mendapatkan "Ijazah" layaknya yang terjadi pada pendidikan formal sekolah. Keistimewaan mendapatkan ijazah tersebut bukan tanpa usaha, melainkan harus melalui "ujian yang disesuaikan dengan masing-masing tingkat di pendidikan formal", yang juga disesuaikan dengan kurikulum yang ada di pondok pesantren Miftahul Huda Manonjaya. Hal inilah yang membedakan dengan dua pesantren di atas, yaitu pesantren Sukamanah dan pesantren Cipasung. Penyetaraan tersebut tidak lain sebagai antisipasi dalam menghadapi perubahan sosial, baik yang terjadi di masyarakat pada saat para santri belajar, maupun yang terjadi di masyarakat pada saat para santri telah lulus nanti.

34 Hasil wawancara penulis dengan wakil pengurus/ Wakil Ro'is 'Am Pondok Pesantren Miftahul Huda Manonjaya, yaitu Saudara Irham, pada saat berkunjung ke pesantren tersebut.

\section{Fasilitas}

Sama halnya dengan pesantren Sukamanah dan pesantren Cipasung, pesantren Miftahul Huda Manonjaya pun memiliki berbagai fasilitas. Sebagai sebuah lembaga pendidikan, berbagai fasilitas merupakan hal yang sangat urgen keberadaannya. Fasilitas-fasilitas yang dimiliki pesantren Manonjaya ini -begitu sebutan akrab untuk pondok pesantren Miftahul Huda Manonjaya-, diantaranya: Masjid, asrama santri, kantor, asrama pengasuh, dapur, sekolahan, lapangan, koperasi santri, perpustakaan, laboratorium komputer, laboratorium bahasa, gudang, kamarmandi/wc, klinik kesehatan, dan Lembaga Pendidikan. ${ }^{35}$

Fasilitas-fasilitas tersebut umumnya memiliki unsur kesamaan dengan dua pesantren di atas, yaitu pesantren Sukamanah dan pesantren Cipasung. Hal tersebut menurut hemat penulis, sebagai bukti bahwa pesantren Miftahul Huda Manonjaya, meskipun tidak menjalankan pendidikan formal sekolah, tetapi memiliki kepedulian yang tinggi dalam rangka mengantisipasi perubahan sosial yang terjadi, yang sedang, telah, atau akan dihadapi oleh para santri.

\section{Ekstrakurikuler}

Pada masa sekarang, hampir di setiap lembaga pendidikan baik formal maupun non formal, dapat dipastikan memiliki kegiatan ekstrakurikuler, meskipun macam dan jenisnya ada yang sama dan ada pula yang berbeda. Nampaknya, kegiatan ekstrakurikuler tersebut tidak dapat dinafikan lagi oleh setiap lembaga pendidikan formal maupun non formal. Mengapa demikian? Karena kegiatan tersebut diadakan, tidak lain sebagai muatan tambahan untuk bekal para santri/ siswa dalam menghadapi perubahan sosial yang terjadi, pada masyarakat saat ini, atau yang akan datang.

35 Hasil wawancara penulis dengan Wakil Ro'is 'Am Pondok Pesantren Miftahul Huda Manonjaya, dan hasil penelusuran penulis sebagai bukti di lapangan, ketika melakukan survei di Pesantren Miftahul Huda Manonjaya. 
Tidak bedanya dengan Pesantren Sukamanah dan Pesantren Cipasung, disamping kegiatan intrakurikuler yang menjadi standar wajib, kegiatan ekstrakurikuler pun diadakan di pondok pesantren Miftahul Huda Manonjaya ini. Kegiatan ekstrakurikuler tersebut diantaranya:

a. Kajian kitab-kitab kuning (kitab salaf);

b. Pembinaan Tilawatil Qur'an;

c. Latihan berpidato dalam tiga bahasa (Indonesia, Inggris dan Arab);

d. berbahasa Arab dan Inggris sehari-hari;

e. Diskusi dan Penelitian Ilmiah;

f. Kepramukaan;

g. Pengembangan Olahraga;

h. Pengembangan Seni Drumband, Qashidah dan Marawis;

i. Pengembangan Seni Beladiri (Tapaksuci);

j. Tahfidhul Qur'an;

k. Pengembangan jurnalistik dan publisistik; dan

1. Pengembangan Exacta (Lab Skill).

\section{H. Analisis Terhadap Bentuk atau Model dari Ketiga Pondok Pesantren}

Sebagai kerangka acuan untuk mengukur atau mengidentifikasi tentang ciri-ciri pesantren salaf dari ketiga pesantren yang menjadi objek dalam penelitian ini, penulis mengacu pada teori 5 ciri pesantren salaf sebagaimana yang diungkapkan oleh Zamakhsyari Dhofier, yaitu:

1) Kurikulum Pendidikan. Yaitu, bahwa Kurikulum pesantren salaf menekankan pada ilmu agama, terutama meliputi alQur'an, hadits, fikih, akidah, akhlak, sejarah Islam, faraidh (ilmu waris Islam), ilmu falak, ilmu hisab, dan lainlain. Semua materi pelajaran yang dikaji memakai buku berbahasa Arab yang umum disebut dengan kitab kuning, kitab gundul, kitab klasik, atau kitab turats ${ }^{36}$;

2) Metode Belajar. Pada pesantren salaf murni, metode belajar menggunakan sistem bandongan dan sorogan.

36Lihat, www.datdut.com/ciri-pesantren-salafmodern-salafi/. Di akses pada tgl 31 Oktober 2018. pukul 13:25 WIB.
Bandongan atau disebut juga wetonan adalah pengajian kitab oleh kiai atau guru yang membaca kitab dengan makna ala pesantren dan santri mendengar serta menulis makna. Sorogan adalah menyetorkan bacaan kitab kepada salah satu guru yang dipercaya. Dengan kata lain, bandongan dan wetonan adalah pengajian umum, sedangkan sorogan adalah pengajian semacam privat. ${ }^{37}$;

3) Prioritas Keilmuan. Prioritas keilmuan yang ditekankan pada pesantren-pesantren salaf berbeda-beda tergantung jenisnya. Ada pesantren khusus tahfidz, yang lebih menonjolkan hafalan dan tahsin bacaan. Pesantren salaf yang menonjolkan keilmuan di bidang alat (Nahwu, Sharf, Balaghah), lebih mengutamakan kemampuan di bidang ilmu alat untuk menguasai kitab-kitab kuning. Keunggulannya santri salaf lebih mengerti tata bahasa Arab tertulis seperti dalam kitab-kitab kuning dengan mendalam. Untuk bahasa lisan, mereka kurang lancar memakai bahasa Arab. Selain kurang biasa, kosakata yang dimiliki adalah kosakata bahasa Arab fushah (resmi) yang bersumber dari bahasa kitab ${ }^{38}$;

4) Ciri Kultur dan Administrasi. Dalam lingkungan pesantren salaf, didikan ala kitab Ta'lim dan kitab adab lainnya terlihat dalam keseharian santri terhadap kiai, guru dan seniornya. Rata-rata pesantren salaf berafiliasi kultural ke NU dalam fahamnya. Sederhananya, fikihnya Syafi'i, akidah tauhid Asy'ariyah Maturidiyah, tasawuf ala Imam Ghazali, tarawih 20 rakaat plus witir 3 rakaat, qunut dalam shalat subuh, tahlilan, maulid, barzanji, dan lainnya. Keseharian

37Lihat, www.datdut.com/ciri-pesantren-salafmodern-salafi/. Di akses pada tgl 31 Oktober 2018, pukul 13:25 WIB.

38Lihat, www.datdut.com/ciri-pesantren-salafmodern-salafi/. Di akses pada tgl 31 Oktober 2018, pukul 13:25 WIB. 
santri bersarung dan berpakaian sederhana ${ }^{39}$; dan

5) Doktrin Keagamaan. Doktrin keagamaan pada pesantren salaf selalu bercorak ahlussunah wal jamaah versi NU dan sejenisnya, yaitu bercirikan mengikuti salah satu 4 mazhab, mazhab teologi mengikuti Asy'ariyah dan Maturidiyah, menganut tasawuf ala Imam al-Ghazali. $^{40}$

Berdasarkan teori 5 ciri pesantren salaf, penulis akan menjelaskan dari ketiga pesantren yang menjadi objek penelitian ini, melalui tahapan demi tahapan dari 5 ciri pesantren salaf. Penjelasan yang dimaksud yaitu:

1) Pada tahapan kurikulum pendidikan, Pondok Pesantren Sukamanah, selain memiliki sistem pendidikan formal sekolah, pada sistem pendidikan kepesantrenannya masih mengacu pada kurikulum pesantren salaf yang menekankan pada ilmu agama, terutama meliputi al-Qur'an, hadits, fikih, akidah, akhlak, sejarah Islam, faraidh (ilmu waris Islam), ilmu falak, ilmu hisab, dan lainlain. Semua materi pelajaran yang dikaji memakai buku berbahasa Arab yang umum disebut dengan kitab kuning, kitab gundul, kitab klasik, atau kitab turats. Begitu juga dengan Pondok Pesantren Cipasung, disamping pendidikan formal sekolah yang diterapkan, pada sistem pendidikan kepesantrenan pun masih mengacu pada kurikulum pesantren salaf, sebagaimana yang tersebut di atas. Lain halnya dengan Pondok Pesantren Miftahul Huda Manonjaya, sebagai sebuah pesantren yang tidak menggunakan sistem pendidikan formal sekolah, dapat dipastikan bahwa pesantren ini sangat kental dengan kurikulum pendidikan

39 Lihat, www.datdut.com/ciri-pesantren-salafmodern-salafi/. Di akses pada tgl 31 Oktober 2018, pukul 13:25 WIB.

40 Lihat, www.datdut.com/ciri-pesantren-salafmodern-salafi/. Di akses pada tgl 31 Oktober 2018, pukul 13:25 WIB. pesantren salaf sebagaimana telah tersebut di atas. Oleh karena itu menurut penulis, dari ketiga pesantren yang menjadi objek penelitian ini, pada tahapan kurikulum pendidikan, ketiganya masih tergolong sebagai pesantren salaf;

2) Pada tahapan metode belajar, Pondok Pesantren Sukamanah, selain menggunakan metode belajar modern pada pendidikan formal sekolah, pada sistem pendidikan kepesantrenannya masih menggunakan metode pesantren salaf murni, yaitu metode belajar yang menggunakan sistem bandongan dan sorogan. Bandongan atau disebut juga wetonan adalah pengajian kitab oleh kiai atau guru yang membaca kitab dengan makna ala pesantren dan santri mendengar serta menulis makna. Sorogan adalah menyetorkan bacaan kitab kepada salah satu guru yang dipercaya. Dengan kata lain, bandongan dan wetonan adalah pengajian umum, sedangkan sorogan adalah pengajian semacam privat. Hal yang sama juga terjadi pada Pondok Pesantren Cipasung. Terlebih lagi Pondok Pesantren Miftahul Huda Manonjaya, sebagai pesantren salaf yang tidak menggunakan sistem pendidikan formal sekolah, dapat diduga bahwa metode belajar pesantren salaf sebagai sesuatu yang tidak dapat dipisahkan dari pesantren ini;

3) Pada tahapan Prioritas Keilmuan, Pondok Pesantren Sukamanah, pada umumnya masih menggunakan skala prioritas keilmuan yang ditekankan pada pesantren-pesantren salaf, yang menonjolkan keilmuan di bidang alat (Nahwu, Sharf, Balaghah), lebih mengutamakan kemampuan di bidang ilmu alat untuk menguasai kitab-kitab kuning. Keunggulan para santrinya lebih mengerti tata bahasa Arab tertulis seperti dalam kitab-kitab kuning dengan mendalam. Untuk bahasa lisan, Pesantren Sukamanah sangat tidak asing untuk berbahasa Arab dalam percakapan seharihari, karena hal tersebut sudah menjadi kewajiban bahasa dalam percakapan 
sehari-hari. Berbeda dengan pesantren salaf pada umumnya yang kurang lancar memakai bahasa Arab. Selain kurang biasa, kosakata yang dimiliki adalah kosakata bahasa Arab fushah (resmi) yang bersumber dari bahasa kitab. Begitu pula dengan Pondok Pesantren Cipasung, pada umumnya masih menggunakan skala prioritas keilmuan yang ditekankan pada pesantren-pesantren salaf, yang menonjolkan keilmuan di bidang alat (Nahwu, Sharf, Balaghah), lebih mengutamakan kemampuan di bidang ilmu alat untuk menguasai kitab-kitab kuning. Dimana keunggulan para santrinya lebih mengerti tata bahasa Arab tertulis seperti dalam kitab-kitab kuning dengan mendalam. Akan tetapi, pada bahasa lisan, pesantren ini kurang menerapkan penggunaan bahasa Arab, karena hal tersebut tidak terlalu diwajibkan dalam percakapan sehari-hari. Sedangkan Pondok Pesantren Miftahul Huda Manonjaya, yang merupakan representasi dari sebuah pesantren salaf yang tidak menggunakan sistem pendidikan formal sekolah, dapat dipastikan masih menggunakan skala prioritas keilmuan yang ditekankan pada pesantren-pesantren salaf, yang menonjolkan keilmuan di bidang alat (Nahwu, Sharf, Balaghah), dan lebih mengutamakan kemampuan di bidang ilmu alat untuk menguasai kitab-kitab kuning, yang keunggulan para santrinya lebih mengerti tata bahasa Arab tertulis seperti dalam kitab-kitab kuning dengan mendalam. Akan tetapi, dari segi bahasa lisan, pesantren ini kurang lancar memakai bahasa Arab. Selain kurang biasa, kosakata yang dimiliki adalah kosakata bahasa Arab fushah (resmi) yang bersumber dari bahasa kitab;

4) Pada tahapan Ciri Kultur dan Administrasi, Pondok Pesantren Sukamanah, Pondok Pesantren Cipasung, dan Pondok Pesantren Miftahul Huda Manonjaya, didikan ala kitab Ta'lim alTa'lim, dan kitab adab lainnya terlihat dalam keseharian santri terhadap kiai, guru dan seniornya di pesantre-pesantren tersebut. Hal itu menjadi ciri khas yang sangat kental di lingkungan pesantren salaf. Oleh karenanya, pada tahapan ini, ketiga pesantren tersebut masuk pada katagori pesantren salaf. Kemudian, yang menjadi ciri lain dari pesantren salaf adalah rata-rata berafiliasi kultural ke NU dalam fahamnya. Sederhananya, fikihnya Syafi'i, akidah tauhid Asy'ariyah Maturidiyah, tasawuf ala Imam Ghazali, tarawih 20 rakaat plus witir 3 rakaat, qunut dalam shalat subuh, tahlilan, maulid, barzanji, keseharian santri bersarung dan berpakaian sederhana. Ciriciri tersebut juga ada pada pesantren Sukamanah, pesantren Cipasung, dan pesantren Miftahul Huda Manonjaya; dan

5) Pada tahapan yang terakhir, yaitu tahapan Doktrin Keagamaan, Pesantren Sukamanah, Pesantren Cipasung, dan Pesantren Miftahul Huda Manonjaya, sama-sama memiliki doktrin keagamaan yang umum digunakan pada pesantren salaf, yaitu doktrin yang selalu bercorak ahlussunah wal jamaah versi NU dan sejenisnya, bercirikan mengikuti salah satu 4 mazhab, mazhab teologi yang dianutnya mengikuti Asy'ariyah dan Maturidiyah, dan mengikuti tasawuf ala Imam al-Ghazali.

Dari kesamaan-kesamaan pada sisi pendidikan kepesantrenan, ketiga pesantren tersebut sama-sama memiliki ciri khusus yang umum dimiliki oleh pesantren salaf. Oleh karenanya menurut penulis, ketiga pesantren tersebut dapat dikatakan sebagai pesantren salaf, meskipun dua pesantren yaitu pesantren Sukamanah dan pesantren Cipasung menggabungkannya dengan sistem pendidikan formal, sedangkan pesantren Miftahul Huda Manonjaya bertahan dengan sistem pesantren semi formal, dalam artian tidak menggunakan sistem pendidikan formal sekolah, tetapi mendapat penyetaraan status, dan tidak asing dengan sentuhan-sentuhan modern pada kegiatan ekstrakurikulernya.

Dengan demikian, ketiga pesantren tersebut di satu sisi dapat dikatakan sebagai pesantren salaf dengan teori 5 ciri pesantren salaf 
menurut Zamakhsyari Dhofier, yaitu: kurikulum pendidikan, metode belajar, Prioritas Keilmuan, Ciri Kultur dan Administrasi, dan Doktrin Keagamaan. Akan tetapi pada sisi lain menggunakan sentuhansentuhan modern. Pesantren Sukamanah dan Pesantren Cipasung menjabarkan sentuhan modern tersebut dengan sistem pendidikan formal sekolah, sedangkan pesantren Miftahul Huda Manonjaya menjabarkannya dengan sistem semi formal tanpa sekolah formal.

Pada kesimpulannya, bentuk ketiga pesantren tersebut sama-sama memiliki 5 ciri pesantren salaf yang menggunakan sentuhansentuhan modern, baik secara formal maupun non formal. Namun ketiganya tidak sama dengan pesantren salaf tempo dulu yang jauh dari sentuhan-sentuhan perkembangan modern.

\section{Analisis Terhadap Perubahan Yang Terjadi Pada Ketiga Pondok Pesantren dan Faktor Pendorongnya}

Menurut penulis, perubahan yang terjadi dari ketiga Pondok Pesantren tersebut, serta faktor pendorong terjadinya perubahan, yaitu: pertama, pengadaan pendidikan formal disamping pendidikan pesantren salaf sistem klasikal yang telah ada, merupakan suatu perubahan yang terjadi, karena terdapat faktor pendorongnya, yaitu untuk memberikan keseimbangan dalam kualitas, dan menjawab tantangan yang dibutuhkan masyarakat pada era kontemporer ini.

Kedua, dari yang hanya kegiatan kepesantrenan, yang lebih dikenal dengan Pesantren Sukahideng-Sukamanah dengan fasilitas seadanya, kemudian didirikan-lah "Yayasan K.H. Zainal Musthafa Sukamanah", merupakan perubahan yang terjadi, karena terdapat faktor pendorongnya, yaitu untuk melanjutkan perjuangan pahlawan nasional K.H. Zainal Musthafa dalam rangka menjunjung tinggi martabat kalimat Allah melalui pendidikan dan pengajaran.

Ketiga, dari pesantren salafiyah murni, kemudian dipadukan dengan sistem pendidikan formal sekolah, merupakan perubahan yang terjadi, karena terdapat faktor pendorongnya, yaitu pendidikan formal akan mampu melahirkan para intlektual di bidang ilmu pengetahuan dan teknologi. Dimana hal ini, sesuatu yang tidak dapat diketemukan pada sistem pendidikan pesantren salaf.

Keempat, pada awalnya, pesantren yang hanya menggunakan sistem pendidikan tradisional salafiyah saja, kemudian digunakanlah sistem pendidikan formal sekolah dengan tetap mempertahankan pesantren salaf dengan sistem klasikalnya, Hal itu merupakan perubahan yang terjadi, karena terdapat faktor pendorongnya yaitu, bahwa pesantren salafiyah atau salaf telah terbukti melahirkan banyak ulama yang berkualitas di bidang ilmu agama, yang pada satu sisi keagamaan tidak mampu ditandingi oleh produk sistem pendidikan apapun, termasuk pendidikan formal, dan

Kelima, pesantren tradisional salafiyah murni dengan metode pengajaran yang sangat tradisional, kemudian bergeser kepada pesantren salafiyah dengan sistem pengajaran klasikal, yang pada akhirnya bergeser lagi pada sistem pendidikan semi formal yang berjenjang, yang dipandu dengan kurikulum dan silabus yang disusun oleh pendiri pesantren Almarhum KH. Choer Affandy, atau yang lebih akrab dipanggil Uwa Ajengan Manonjaya. Dimana masing-masing jenjang ditempuh selama 3 tahun dengan materi pelajaran mulai pada tingkat ibtida', kemudian tingkat tsanawi, dan diakhiri dengan tingkat ma'had 'aly dengan sistem semi formal. hal itu merupakan perubahan yang terjadi oleh karena terdapat faktor pendorongnya, yaitu kebutuhan terhadap penyetaraan status yang berijazah, yang setara dengan pendidikan formal sekolah pada umumnya.

\section{J. Kesimpulan}

Dari uraian di atas, dapat ditarik beberapa kesimpulan bahwa:

1. Dari kesamaan-kesamaan pada sisi pendidikan kepesantrenan, ketiga pesantren tersebut sama-sama memiliki ciri khusus yang umum dimiliki oleh pesantren salaf. Dengan demikian, ketiga pesantren yang menjadi objek penelitian ini, di satu sisi dapat dikatakan sebagai pesantren salaf dengan teori 5 ciri pesantren salaf menurut 
Zamakhsyari Dhofier, yaitu: kurikulum pendidikan, metode belajar, Prioritas Keilmuan, Ciri Kultur dan Administrasi, dan Doktrin Keagamaan. Akan tetapi pada sisi lain menggunakan sentuhan-sentuhan modern. Pesantren Sukamanah dan Pesantren Cipasung menjabarkan sentuhan modern tersebut dengan sistem pendidikan formal sekolah, sedangkan pesantren Miftahul Huda Manonjaya menjabarkannya dengan sistem semi formal tanpa sekolah formal.

Pada kesimpulannya, bentuk ketiga pesantren tersebut sama-sama memiliki 5 ciri pesantren salaf yang menggunakan sentuhan-sentuhan modern, baik secara formal maupun non formal. Namun ketiganya tidak sama dengan pesantren salaf tempo dulu yang jauh dari sentuhansentuhan perkembangan modern;

2. Perubahan-perubahan yang terjadi serta faktor pendorongnya pada Pesantren Sukamanah, Pesantren Cipasung, dan Pesantren Miftahul Huda Manonjaya, pertama, pengadaan pendidikan formal disamping pendidikan pesantren salaf sistem klasikal yang telah ada, merupakan suatu perubahan yang terjadi, karena terdapat faktor pendorongnya, yaitu untuk memberikan keseimbangan dalam kualitas, dan menjawab tantangan yang dibutuhkan masyarakat pada era kontemporer ini. Kedua, dari yang hanya kegiatan kepesantrenan, yang lebih dikenal dengan Pesantren Sukahideng-Sukamanah dengan fasilitas seadanya, kemudian didirikan-lah "Yayasan K.H. Zainal Musthafa Sukamanah", merupakan perubahan yang terjadi, karena terdapat faktor pendorongnya, yaitu untuk melanjutkan perjuangan pahlawan nasional K.H. Zainal Musthafa dalam rangka menjunjung tinggi martabat kalimat Allah melalui pendidikan dan pengajaran. Ketiga, dari pesantren salafiyah murni, kemudian dipadukan dengan sistem pendidikan formal sekolah, merupakan perubahan yang terjadi, karena terdapat faktor pendorongnya, yaitu pendidikan formal akan mampu melahirkan para intlektual di bidang ilmu pengetahuan dan teknologi. Dimana hal ini, sesuatu yang tidak dapat diketemukan pada sistem pendidikan pesantren salaf. Keempat, pada awalnya, pesantren yang hanya menggunakan sistem pendidikan tradisional salafiyah saja, kemudian digunakanlah sistem pendidikan formal sekolah dengan tetap mempertahankan pesantren salaf dengan sistem klasikalnya, Hal itu merupakan perubahan yang terjadi, karena terdapat faktor pendorongnya yaitu, bahwa pesantren salafiyah atau salaf telah terbukti melahirkan banyak ulama yang berkualitas di bidang ilmu agama, yang pada satu sisi keagamaan tidak mampu ditandingi oleh produk sistem pendidikan apapun, termasuk pendidikan formal. Kelima, pesantren tradisional salafiyah murni dengan metode pengajaran yang sangat tradisional, kemudian bergeser kepada pesantren salafiyah dengan sistem pengajaran klasikal, yang pada akhirnya bergeser lagi pada sistem pendidikan semi formal yang berjenjang, yang dipandu dengan kurikulum dan silabus yang disusun oleh pendiri pesantren Almarhum $\mathrm{KH}$. Choer Affandy, atau yang lebih akrab dipanggil Uwa Ajengan Manonjaya. Dimana masing-masing jenjang ditempuh selama 3 tahun dengan materi pelajaran mulai pada tingkat ibtida', kemudian tingkat tsanawi, dan diakhiri dengan tingkat ma'had 'aly dengan sistem semi formal. hal itu merupakan perubahan yang terjadi oleh karena terdapat faktor pendorongnya, yaitu kebutuhan terhadap penyetaraan status yang berijazah, yang setara dengan pendidikan formal sekolah pada umumnya. Demikianlah kesimpulan tentang kajian Pesantren Salaf: Perubahan Sosial dan Sublimasi Identitas (Model Pesantren di Kabupaten Tasikmalaya Jawa Barat) yang dapat penulis sampaikan.

\section{DAFTAR PUSTAKA}

Arief, Muhammad. "Pondok Pesantren Transformatif Sebuah Masyarakat Futurologis Kebutuhan Masyarakat Era Globalisas". Al-Hikmah, Volume 1 Nomor 2. September, 2011. 
Azra, Azyumardi. Pendidikan Islam; Tradisi dan Modernisasi di Tengah Tantangan Milenium III. Jakarta: Kencana, 2012.

Bawani, Imam. Tradisionalisme dalam Penddidikan Islam; Studi Tentang Daya Tahan Pesantren Tradisional. Surabaya: Al-Ikhlas, 1993.

Corporation, Microsoft. Encarta Dictionaries. Microsoft ${ }^{\circledR}$ Encarta ${ }^{\circledR}, 2009$.

Campbell, Tom. Tujuh Teori Sosial: sketsa, Penilaian, Perbandingan. Yogyakarta: Kanisius, 2001.

Dhofier, Zamakhsyari. Tradisi Pesantren: Studi tentang Pandangan Hidup Kyai. Jakarta: LP3ES, 1982.

Gus Dur. Menggerakan Tradis: Esei-esei Pesantren. Yogyakarta: LKiS, 2001.

http://portalsemarang.com/tantangan-terkinipesantren-salaf/ diakses Oktober 2017

https://www.kompasiana.com/ di akses Oktober 2017

http://www.muslimedianews.com/2015/05/pon pes-lirboyo-berubah-haluan-jadi-ldii.html, diakses 6 Oktober 2017

http://www.nu.or.id/post/read/13817/problema tika-pesantren-salaf-masa-kini, diakses 12 Oktober 2017

https://www.alkhoirot.com/beda-pondokmodern-dan-pesantren-salaf/\#2, 3. Di akses pada tgl. $\quad 01 / 07 / 2018$, pukul 7:31.

http://id.wikipedia.org/wiki/Pondok_Pesantren Cipasung

Kartodirdjo, Sartono. Protest Movement in Riyayi Dalam Masyarakat Jawa. Kualalumpur: Oxford University Press, 1987

Murtadho, M. "Pesantren Salaf dan Perubahan Sosial". Jurnal Penelitian Pendidikan Agama dan Keagamaan Edukasi. Volume. 10, Nomor 1, Januari-April, 2012.

Muliawan, Jasa Ungguh. Pendidikan Islam Integratif; Upaya Mengintegrasikan Kembali Dikotomi Ilmu dan Pendidikan Islam. Yogyakarta: Pustaka Pelajar, 2005.

Madjid, Nurcholish. Bilik-Bilik Pesantren: Sebuah Potret Perjalanan. Jakarta: Paramadina, 1997.

Poerwandari, Kristi. Pendekatan Kualitatif untuk Penelitian Perilaku Manusia. Ed. Ke-3, Depok: LPSP3 FPUI, 2005.

Poerkawatja, Soegarda. Ensiklopedia Pendidikan. Jakarta: Gunung Agung, 1976.

Prima Pena, Tim. Kamus Lengkap Bahasa Indonesia. tk.: Gitamedia Press, tt.

Putra Daulay, Haidar. Sejarah Pertumbuhan dan Pembaruan Pendidikan Islam di Indonesia.Jakarta: Kencana Prenada Media Grup, 2007.

Redaksi Kamus Bahasa Indonesia, Tim. Kamus Bahasa Indonesia. Jakarta: Pusat Bahasa Departemen Pendidikan Nasional, 2008.

Rhadiatan Mardiah, Tita dari berbagai sumber. http://www.pstkhzmusthafa.or.id/.

Subhan, Arief. Lembaga Pendidikan Islam Indonesia Abad Ke-20: Pergumulan antara Modernisasi dan Identitas. Jakarta: Kencana, 2012.

Shihab, M. Quraish. Wawasan Al-Qur'an; Tafsir Tematik atas Pelbagai Persoalan Umat. Bandung: PT. Mizan Pustaka, 2007.

Setiawan, Kelik. dan M. Tohirin. Format Pendidikan Pondok Pesantren Salafi Dalam Arus Perubahan Sosial Di Kota Magelang. Fakultas Agama Islam Universitas Muhammadiyah Magelang. Cakrawala. Vol. X. No. 2. Desember, 2015. Usa, Muslih. Pendidikan Islam di Indonesia Dalam Transformasi Sosial Budaya:Antara Cita dan Fakta. Yogyakarta: Tiara Wacana, 1991.

www.masjidjami-alittihad-citraindah.com/ www.datdut.com/ciri-pesantren-salaf-modernsalafi/. Di akses pada tgl 31 Oktober 2018, pukul 13:25 WIB. 